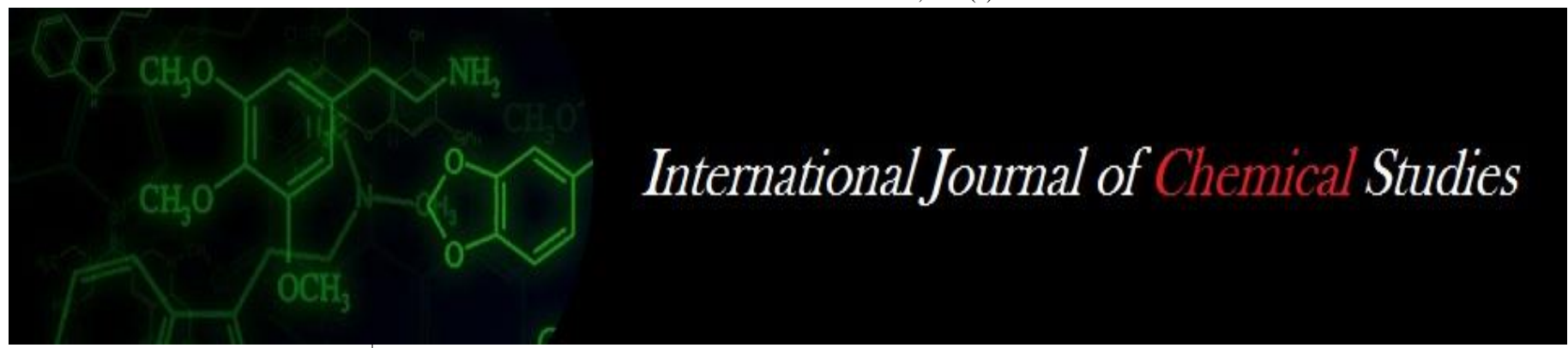

P-ISSN: 2349-8528

E-ISSN: 2321-4902

www.chemijournal.com

IJCS 2021; SP-9(1): 76-80

(C) 2021 IJCS

Received: 11-11-2020

Accepted: 18-12-2020

DP Singh

Senior Scientist and Head,

Krishi Vigyan Kendra,

ANDUAT, Basuli, Maharajganj,

Uttar Pradesh, India

V Chandra

Associate Professor/SMS (AS),

Krishi Vigyan Kendra,

ANDUAT, Basuli, Maharajganj,

Uttar Pradesh, India

T Tiwari

Programme Assistant,

Krishi Vigyan Kendra,

ANDUAT, Basuli, Maharajganj,

Uttar Pradesh, India
Corresponding Author: DP Singh

Senior Scientist and Head,

Krishi Vigyan Kendra,

ANDUAT, Basuli, Maharajganj,

Uttar Pradesh, India

\section{Compatibility of sulfosulfuron and metsulfuron- methyl for the control of complex weed Phalaris minor in wheat through frontline demonstrations of eastern Uttar Pradesh}

\author{
DP Singh, V Chandra and T Tiwari
}

DOI: https://doi.org/10.22271/chemi.2021.v9.i1b.11434

\begin{abstract}
Front Line Demonstration is one of the most powerful tools for transfer of technology. The present study was undertaken to find out the yield gap through FLDs on wheat crop. Krishi Vigyan Kendra, Maharajganj, Eastern U.P. conducted 75 front line demonstration on wheat crop at farmers field of fifteen adopted villages during 2018-19 and 2019-20 for transfer of technology. In two consecutive year demonstration programme of improved wheat production technology on wheat variety HD 2967 demonstrate production potential and economic benefit of improved technologies consisting herbicidal management. Application of Sulfosulfuron + Metsulfuron $32 \mathrm{~g} / \mathrm{ha}$ resulted in significantly lower plant population of Phalaris minor followed by effect of Isoproturon + 2,4-D $(1000+500 \mathrm{~g} / \mathrm{ha})$ application resulted in more number of $P$. minor. Grain yield were significantly higher in treated plots as compared to the control Sulfosulfuron + Metsulfuron $32 \mathrm{~g} / \mathrm{ha}$ gave maximum grain yield $36.05 \mathrm{q} / \mathrm{ha}$ compared to control $22.85 \mathrm{q} / \mathrm{ha}$, which could possibly use for herbicides control in wheat crop with a considerable higher yield. The extension gap and technology gap were observed to be $13.20 \mathrm{q} / \mathrm{ha}, 13.95 \mathrm{q} / \mathrm{ha}$ respectively. The technology index (\%) of $27.90 \%$. Technology index was recorded to be decreased over the successive years of study the successive decreased value of technology index reflected the feasibility of the demonstrated technology in agro - climatic condition of eastern Uttar Pradesh.
\end{abstract}

Keywords: Herbicides, technology index, technology gap, BC ratio, extension gap, grain yield

\section{Introduction}

Wheat (Triticum aestivum L.) is the second most important cereal crop of India and plays a vital role in food and nutritional security of the country. Nearly 55 per cent of the world population depends on wheat for about 20 per cent of calories intake. It is one of the major food grains of the country and a staple food of the people of North India, where people have preference for chapatti. The diverse environmental conditions and food habits of people in India supports the cultivation of three types of wheat (bread, durum and dicoccum). Among these, bread wheat is contributing approximately 95 per cent to total production while another 04 per cent comes from durum wheat and close to one per cent from Dicoccum. In India, wheat cultivated on $29.6 \mathrm{~m}$ ha area with $93.5 \mathrm{~m}$ tonnes of production and $31.5 \mathrm{q} / \mathrm{ha}$ of average productivity $(\mathrm{FAO}, 2013)^{[8]}$. In Uttar Pradesh, it is grown on $9.73 \mathrm{~m}$ ha area with production $30.3 \mathrm{~m}$ tons and productivity of $31.14 \mathrm{q} /$ ha (Anonymous, 2013) ${ }^{[1]}$. The requirement of wheat will be around 109 million tonnes for feeding the 1.25 billion populations by 2020 AD (Singh, $2010)^{[10-12]}$. Wheat is the world's most widely cultivated food crop. Average yield losses due to weeds are $20-30 \%$, however, heavy infestation of the formidable weeds can inflict huge crop losses (Singh et al. 1999) ${ }^{[10-12]}$. Grassy weeds like Phalaris minor and Avena ludoviaciana are dominant in rice-wheat rotation in North West plain zone. Continuous use of a particular herbicide may develop resistance in weeds. Herbicide mixtures may be an alternative for management or delay of cross resistance development against these herbicides (Dhawan et al. 2009) ${ }^{[7]}$. Keeping in view the above facts, the present investigation was undertaken to test the performance of herbicides alone or in combination to control weeds in wheat. Sulfosulfuron has been reported to provide effective control of isoproturon resistant 
Phalaris minor along with marginal control of broadleaf weeds in wheat (Yadav and Malik, 2005) ${ }^{[2, ~ 15] . ~ T h e ~}$ combinations of 2, 4-D and metsulfuron with clodinafop, fenoxaprop and sulfosulfuron were found incompatible as tank mixture (Banga and Yadav, 2004; Singh and Singh, 2005) $[2,10-12,15]$. However, sequential applications of these herbicides were found suitable for the control of broad spectrum weeds. But some of the problematic weeds like Malwa parviflora L. and Convolvulus arvensis L. have started emerging in wheat fields which are not effectively controlled either by metsulfuron or 2,4-D. Carfentrazone-ethyl has already been reported very effective against most of the broadleaf weeds including these problematic weeds (Cauchy, 2000; Singh et al., 2004; Walia and Singh, 2006) ${ }^{[3,10-12,13] .}$

Providing effective extension service is inevitable to break the existing resistance by awareness creation through demonstration at farmers training centre. Complementary wheat technologies including tillage frequency, seed treatment, sowing techniques, genetically improve seed, disease, insect and weed management practice have to be provided to boost wheat production and to be change the livelihood of Indian farmers. However, most of the frontline demonstrations results have been presented in the form of yield and economic advantages and hence, quantification of yield gap minimized because of the demonstrations becomes an important area of investigation.

\section{Materials and Methods}

The present study was carried out by Krishi Vigyan Kendra Basuli, Maharajganj, Achrya Narendra Dev University of Agriculture and Technology, Kumarganj, Ayodhya for two consecutive years from 2018-19 and 2019-20 of the farmers field in five blocks viz. Nichlaul, Siswa Bazar, Ghughli and Laxmipur of Maharajganj district through front line demonstration. To evaluate the compatibility of sulfosulfuron @ 45g/ha and Metsulfuron-methyl and 2, 4-D @ 32+500 g/ha against complex weed flora in wheat. Front Line Demonstration is one such powerful tool for transfer of technology which practically exhibits the strength of new technologies in increasing yield and profit. Total 75 demonstrations were conducted in different village's viz. Blaihhore, Bhujanli, Khutamaida and Idupmmathiya 75 farmer's on 30.0 ha lands. Each frontline demonstration was laid out on 0.4 ha area while adjacent 0.4 ha was considered as control for comparison (farmer's practice). The knowledge level of the farmers in these villages was also evaluated by random sample of 20 farmers each village. Thereby sample included 400 numbers of farmers in the study. The farmers were asked to reply questions about the improved agro techniques including the high yielding varieties of wheat. The score so obtained under various questions were summed up. On the basis of the total score obtained, respondents were categorized on to three classes' i.e. low, medium and high level of knowledge. The soils of FLDs field were found sandy loam. Amendments for soil surface crusting: To tide over the soil surface crusting apply lime at the rate of $2 t /$ ha along with FYM at $12.5 \mathrm{t} / \mathrm{ha}$. Treat the seeds with Carbendazim or Thiram@ $2 \mathrm{~g} / \mathrm{kg}$ of seed 24 hours before sowing (or) with talc formulation of Trichoderma viride @ 4g/ $/ \mathrm{kg}$ of seed (or) Pseudomonas fluorescens @10 g/kg seed. Combined effect of sulsufuron + metsulfuron. Isoproturon + 2,4-D $(1000+500$ $\mathrm{g} / \mathrm{ha}$ ) application resulted in more number of $\mathrm{P}$. minor plant as compared to other mixed herbicides application which might be due to resistance of $P$. minor to isoproturon. Initially up to 30 DAS, no significant difference in population of $P$. minor was recorded because no herbicide treatments were imposed in different plots of the experiment. The experimental plots were dominated mainly by $P$. minor Retz. Coronopus didymus Sw., Anagallis arvensis L., Melilotus indica All. Fl. Ped., Medicago denticulata L., Rumex dentatus L., Vicia sativa L. and Lathyrus aphaca L. were the major broadleaved weeds. Recommended dose of fertilizer 120:60:40:25 NPKZnSo4 kg/ha was applied in all the demonstrations. To manage the assessed problems seeds of wheat variety HD 2967 , fertilizer and plant protection chemicals were provided to the farmers as critical inputs and scientific recommended technologies were followed as intervention during the course of front line demonstration programme. The wheat crop was sown at $22.5 \mathrm{~cm}$ (row-row) apart in line using seed rate of 100 $\mathrm{kg} / \mathrm{ha}$ in 2 nd week of November during both the years. Crop was harvested on the same time of harvesting of demonstration plots. Before conduct the demonstration training to farmers of respective village was imparted with respect to envisaged technological interventions. All other steps like site selection, farmers selection, layout of demonstration, farmers participation etc. were followed as suggested by (Choudhary 1999) ${ }^{[4]}$. The data on seed yield, cost of cultivation and gross and net monetary return were collected from technological demonstration plot. In addition to this, data on farmer practices were also collected from the equal area. The benefit cost $(\mathrm{B}: \mathrm{C})$ ratio was calculated based on gross return. The following formulae were used to calculate the parameters as suggested by (Das et al. 1998) ${ }^{[5]}$ :

1. Increase in grain Yield = Grain yield from Demo plot Grain yield from FP plot/Grain yield from Demo plot X 100

2. Net Return $=$ Gross Return - Cost of cultivation

3. Benefit/Cost Ratio $=$ Gross Return/Cost of Cultivation $\mathrm{X}$ 100

The responses were recorded and converted in to mean percent score and ranked accordingly as per (Warde et al. 1991) ${ }^{[14]}$. From front line demonstration plots and farmers practice plot (control plot) and finally extension gap, technology gap, and technology index were calculated as given as formula suggested by (Samui et al. 2000 and Dayanand et al. 2012) ${ }^{[6]}$ as given below.

1. Technology gap $=$ Potential yield - Demonstration yield

2. Extension gap $=$ Demonstration yield - farmers yield

3. Technology index $=[$ (Potential yield - Demonstration yield)/Potential yield ] x 100

The distribution of beneficiaries according to their change of area after conducting the FLD on their field. Unfortunately use of local varieties and poor nutrient management results in very low yield.

\section{Results and Discussion \\ Weeds were major constraints in wheat production total weed density}

All treatments significantly affected total weed density as compared with control (Table 1). Herbicide sulfosulfuron + metsulfuron $32 \mathrm{~g} / \mathrm{ha}$ excelled in reducing total weed density $(90.20 \%)$ followed by $73.27 \%$ as compared to control.

\section{Total weed dry weight $(\mathrm{g} / \mathrm{m} 2)$}

A significant difference among treatments was also observed for weed dry weight suppression as compared with control (Table 1). sulfosulfuron + metsulfuron $32 \mathrm{~g} / \mathrm{ha}$ resulted in the highest reduction in weed biomass $(87.73 \%)$ over control. 
Other treatments Isoproturon + 2,4-D $(1000+500 \mathrm{~g} / \mathrm{ha})$ were statistically at par and comparable to one other in weed biomass $73.39 \%$.

\section{Constraints in wheat production}

On perusal of data presented table -2 it was found that major constraints in wheat production were non availability of the quality seed of high yielding varieties $(88.00 \%)$ was given the top most rank followed by low technical knowledge $(70.67 \%)$, weed infestation $(65.33 \%)$, Use of higher seed rate (58.67\%), low fertility status $(70.67 \%)$ and damage of crop by the wild animals (44.00\%),

\section{Yield}

The data on wheat yield (Table 4 and Figure 2) indicated that the frontline demonstration had given a good impact on the farming community of Maharajganj district as they were motivated by the new agricultural technologies adopted in the demonstrations. Frontline technology gave mean wheat yield of $36.05 \mathrm{q} / \mathrm{ha}$ which was higher by $57.86 \%$ over the prevailing farmers practice $(22.85 \mathrm{q} / \mathrm{ha})$. The results are in close conformity with the (Sharma et al. 2016).

\section{Extension gap, technology gap and technology index}

The technology gap observed may be attributed to dissimilarity in the soil fertility status and weather conditions. Hence location specific recommendation appears to be necessary to bridge the gap between the yields. The highest extension gap of 13.40 was recorded during 2018-19 which emphasized the need to educate the farmers through various means for the adoption of improved high yielding varieties and newly improved agricultural technologies to reverse this trend of wide extension gap. More and more use of new HYV's by the farmers will subsequently change this alarming trend of galloping extension gap (Hedge, 2004). This high extension gap in all these varieties requires urgent attention from planners, scientists, extension personnel and development departments. The lower the value of technology index more is the feasibility of the technology, the new technologies. Will eventually lead to the farmers to discontinuance of old varieties with the new technology, the technology index shows the feasibility of the evolved technology at the farmers' field. The technology index is 29.00 and 26.80 percent during two years study, respectively which shows the good performance of wheat in Maharajganj conditions and this will accelerate the adoption of. Newer technologies to increase the productivity of sesame in this area. These results are in conformity with the findings of (Sagar and Ganesh Chandra 2004) ${ }^{[9]}$.

\section{Economics}

The economic viability of improved demonstrated technology over farmers practice was calculated depending on prevailing price of inputs and outputs cost and represented in the term of $\mathrm{B}: \mathrm{C}$ ratio (Table $5 \&$ Figure 3 ). It was found that the cost of production of wheat under demonstration with an average Rs.30644 under control. The additional cost increased in demonstration was mainly due to more cost involved in balanced fertilizer, procurement of improved seed and management of weeds. The cultivation of wheat under improved technologies gave average net return of Rs. $67,864 /$ ha which was lower Rs. $43,015 /-$ in farmer's practices. The benefit cost ratio of wheat with an average of 2.21 in demonstration plots and 1.88 farmers practice. This may be due to higher yield obtained and lower cost of cultivation under improved technologies compared to farmers practice. There is a need to adopt multipronged strategy which involves enhancing wheat production through horizontal and vertical expansion and productivity improvements through better adoption of improved technology. In the fragile environments and poor farm resource base, wheat is the best choice for farmers.

Table 1: Effect of various weedicides and hand weeding on total weed density and weed dry weight in wheat

\begin{tabular}{|c|c|c|c|c|c|c|c|c|}
\hline \multirow[t]{2}{*}{ Treatments } & \multicolumn{2}{|c|}{$\begin{array}{l}\text { Total weed } \\
\text { density/m }\end{array}$} & \multirow[t]{2}{*}{ Mean } & \multirow{2}{*}{$\begin{array}{l}\% \text { decrease } \\
\text { over control }\end{array}$} & \multicolumn{2}{|c|}{$\begin{array}{c}\text { Total weed dry weight } \\
(\mathrm{g} / \mathrm{m} 2)\end{array}$} & \multirow[t]{2}{*}{ Mean } & \multirow{2}{*}{$\begin{array}{c}\% \text { decrease over } \\
\text { control }\end{array}$} \\
\hline & 2018 & 2019 & & & 2018 & 2019 & & \\
\hline T1-Sulfosulfuron + Metsulfuron $32 \mathrm{~g} / \mathrm{ha}$ & 5.40 & 6.60 & 6.00 & 90.20 & 6.11 & 7.56 & 6.84 & 87.73 \\
\hline T2-Isoproturon + 2,4-D $(1000+500 \mathrm{~g} / \mathrm{ha})$ & 15.43 & 17.33 & 16.38 & 73.27 & 13.96 & 15.69 & 14.83 & 73.39 \\
\hline T3-Hand hoeing (two) & 16.60 & 19.90 & 18.25 & 70.21 & 14.40 & 16.90 & 15.65 & 71.92 \\
\hline T4-Control farmers practice & 60.63 & 61.92 & 61.28 & - & 54.90 & 56.60 & 55.75 & - \\
\hline
\end{tabular}

\section{Performance of weedicide}

-Total weed density/m Total weed dry weight $(\mathrm{g} / \mathrm{m} 2)$

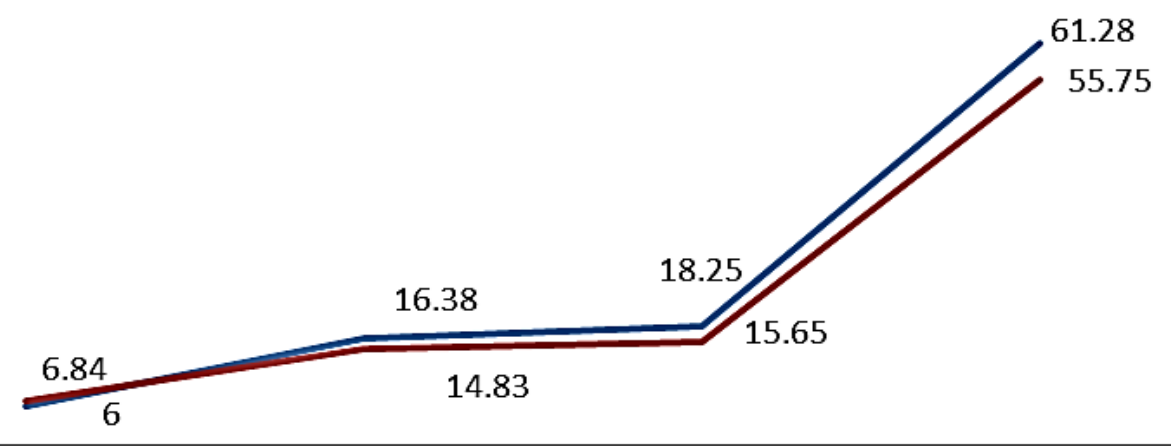

T1-Sulfosulfuron + T2-Isoproturon + 2,4-D T3-Hand hoeing (two) T4-Control farmers Metsulfuron $32 \mathrm{~g} / \mathrm{ha} \quad(1000+500 \mathrm{~g} / \mathrm{ha})$ pratice

Fig 1: Effect of various weedicides of wheat 
Table 2: Ranks for different constraints $(f=75)$ given by farmers

\begin{tabular}{|c|c|c|c|c|}
\hline S. No. & Constraints & Farmers & Percentage & Rank \\
\hline 1 & Non availability of the seeds of high yielding varieties & 66 & 88.00 & I \\
\hline 2 & Low technical knowledge & 53 & 50.67 & II \\
\hline 3 & Use of higher seed rate & 44 & 54.67 & IV \\
\hline 4 & Low soil fertility & 41 & 65.33 & V \\
\hline 5 & Weed infestation & 49 & 44.00 & III \\
\hline 6 & Damage by bull & 33 & VI \\
\hline
\end{tabular}

Table 3: Cost of cultivation of wheat

\begin{tabular}{|c|c|c|}
\hline Cost of cultivation & Demo & FP \\
\hline Harrowing & 8000 & 8000 \\
\hline Plowing & 4000 & 4000 \\
\hline Seed Dril & 4000 & - \\
\hline Seetilizer NPK 120:60:40 (Farmers Practice 150:40) & 6088 & 4188 \\
\hline Weedicides & 1000 & - \\
\hline Irrigation & 1000 & - \\
\hline Harvesting & 1100 & 1100 \\
\hline Total Rs. & 5000 & 5000 \\
\hline
\end{tabular}

Table 4: Performance of front line demonstrations (FLD) of wheat

\begin{tabular}{|c|c|c|c|c|c|c|c|c|c|}
\hline & & $\begin{array}{c}\text { Potential grain } \\
\text { yield (q/ha) }\end{array}$ & Grain yield (q/ha) & $\begin{array}{c}\text { \% increase } \\
\text { over FP }\end{array}$ & $\begin{array}{c}\text { Extension gap } \\
(\mathbf{q} / \mathbf{h a})\end{array}$ & $\begin{array}{c}\text { Technology gap } \\
(\mathbf{q} / \mathbf{h a})\end{array}$ & $\begin{array}{c}\text { Technology } \\
\text { index }\end{array}$ \\
\hline Year & No. of demo & Area (Ha) & & Demo & FP & & & & \\
\hline $2018-19$ & 36 & 15 & 50 & 35.50 & 22.10 & 60.63 & 13.40 & 14.50 & 29.00 \\
\hline $2019-20$ & 39 & 15 & 50 & 36.60 & 23.60 & 55.08 & 13.00 & 13.40 & 26.80 \\
\hline Average & 37.5 & 15 & 50 & 36.05 & 22.85 & 57.86 & 13.20 & 13.95 & 27.90 \\
\hline Total & 20 & 30 & - & - & - & - & - & - & - \\
\hline
\end{tabular}

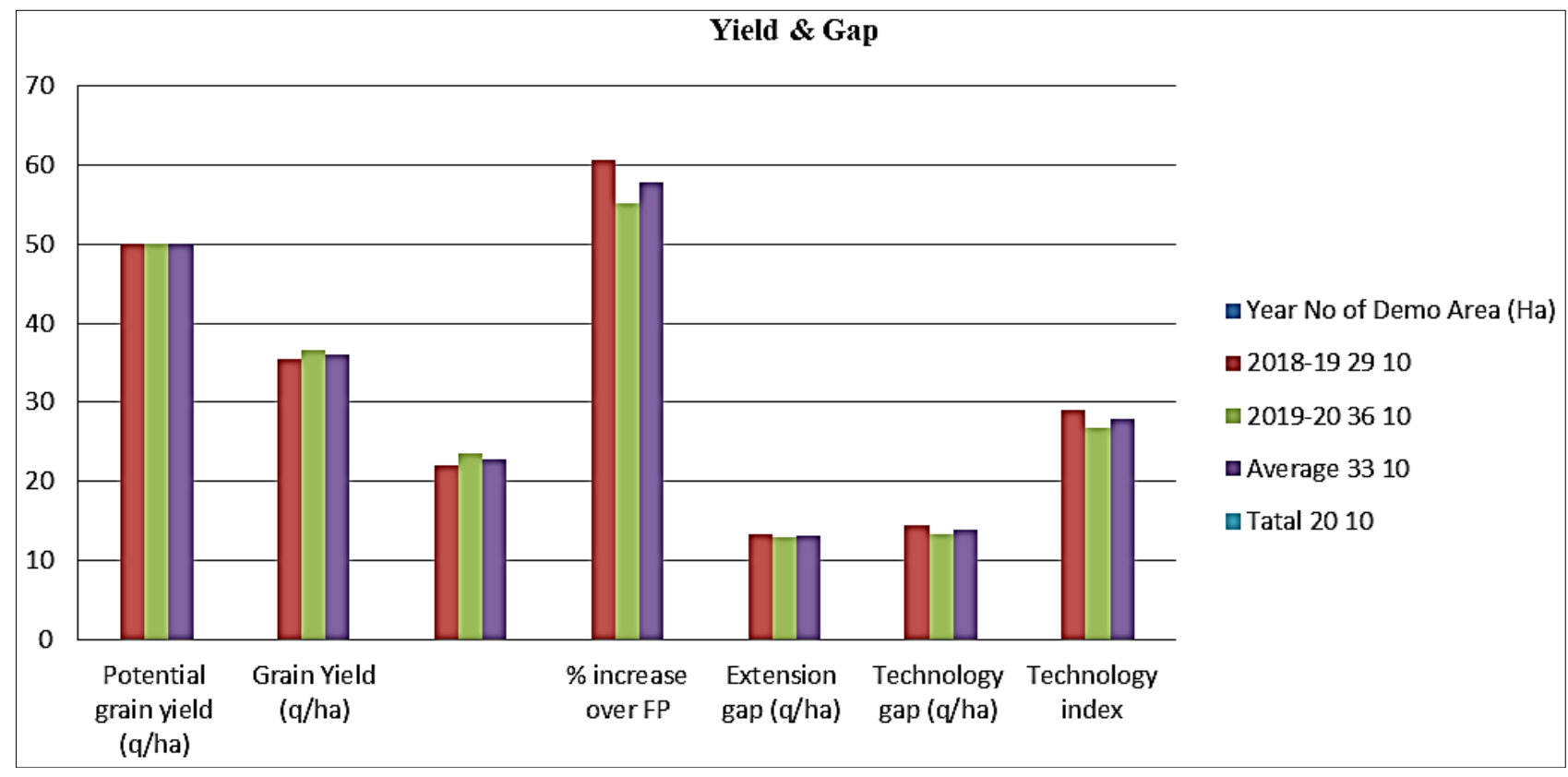

Fig 2: Grain yield and gap of FLD of wheat

Table 5: Seed yield and economics of wheat as affected by improved and local practices in farmers' fields

\begin{tabular}{|c|c|c|c|c|c|c|c|c|c|c|c|c|}
\hline \multirow[t]{2}{*}{ Year } & \multirow[t]{2}{*}{$\begin{array}{l}\text { Potential grain } \\
\text { yield (q/ha) }\end{array}$} & \multicolumn{2}{|c|}{$\begin{array}{c}\text { Cost of cash } \\
\text { input }\end{array}$} & \multirow[t]{2}{*}{$\begin{array}{c}\begin{array}{c}\text { Additional cost in } \\
\text { demonstrations } \\
\text { (Rs./ha) }\end{array} \\
\end{array}$} & \multirow[t]{2}{*}{$\begin{array}{l}\text { Sale price of grain } \\
\quad \text { (MSP) (Rs./qt) }\end{array}$} & \multicolumn{2}{|c|}{$\begin{array}{l}\text { Grain yield } \\
\text { (q/ha) }\end{array}$} & \multicolumn{2}{|c|}{$\begin{array}{l}\text { Total returns } \\
\text { Rs. (ha }\end{array}$} & \multirow[t]{2}{*}{$\begin{array}{c}\text { Extra } \\
\text { returns }\end{array}$} & \multicolumn{2}{|c|}{$\begin{array}{c}\text { Incremental } \\
\text { benefit: Cost ratio }\end{array}$} \\
\hline & & Demo & FP & & & Demo & FP & Demo & FP & & Demo & $\overline{F P}$ \\
\hline 2018 & 5 & 30188 & 22288 & 7 & & 35.50 & 22.10 & 65320 & 40664 & 2 & 6 & .82 \\
\hline $2019-20$ & 50 & 31100 & 23400 & 7700 & & 36.60 & 23.60 & 70455 & 45430 & 39355 & 2.27 & 1.94 \\
\hline Average & 50 & 30644 & 22844 & 7800 & 1883 & 36.05 & 22.85 & 67864 & 43015 & 37220 & 2.21 & 1.88 \\
\hline
\end{tabular}




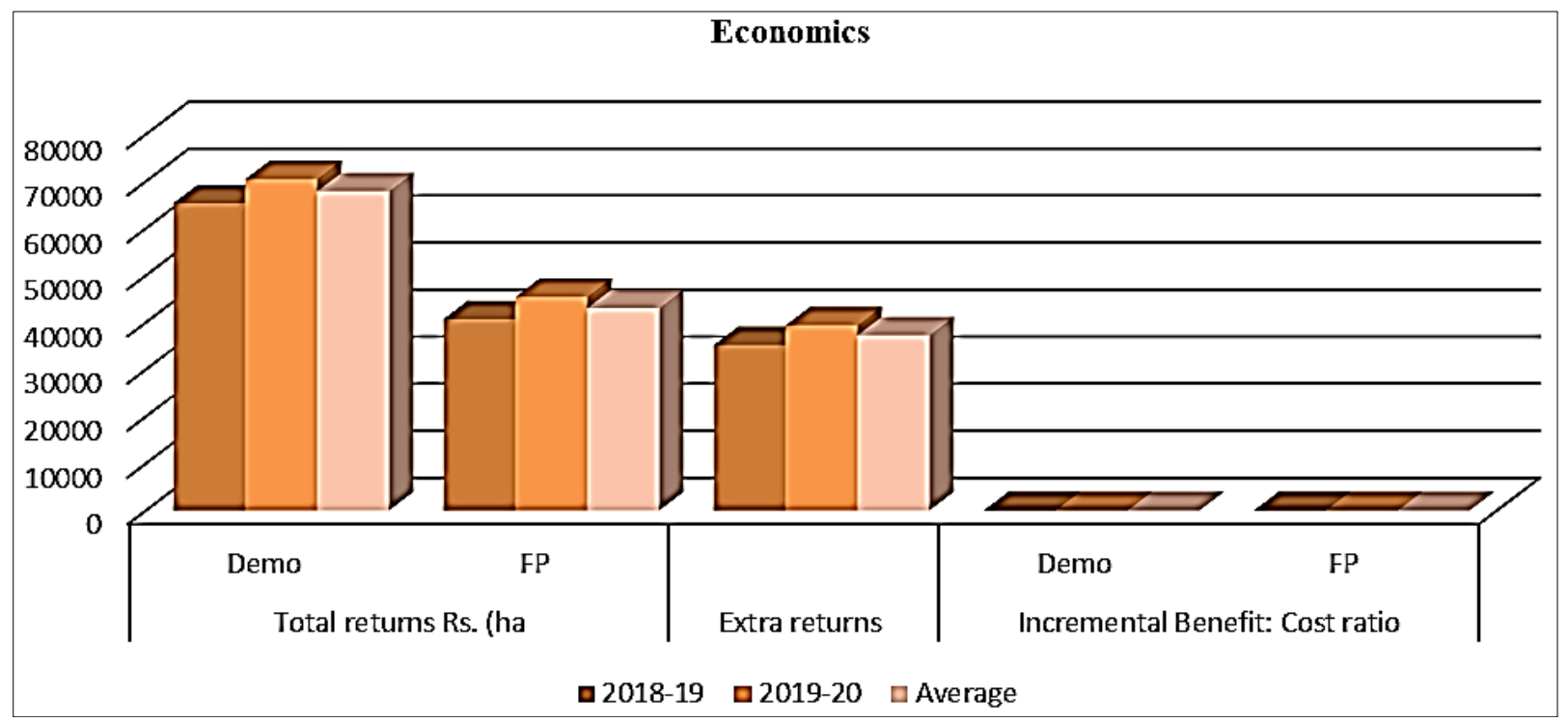

Fig 3: Economics of wheat as affected by improved and local practices in farmers' fields

\section{References}

1. Anonymous. Statistical Abstracts of Punjab 2013. http:// ww.esopb.gov.in/ static/PDF/ Statistical -Abstract2013.pdf

2. Banga RS, Yadav A. Effect of fenoxaprop and sulfosulfuron alone and as tank mixture against complex weeds in wheat. Ind. J Weed Sci 2004;36:163-165.

3. Cauchy P. La carfentrazone-ethyl. Herbicide cereals. Phytoma 2000;531:55-58.

4. Choudhary BN. Krishi Vigyan Kendra-A guide for KVK mangers. Publication, Division of Agricultural Extension, ICAR 1999, P73-78.

5. Das P, Das SK, Mishra PK, Mishra A, Tripathi AK. Farming system analysis of results of front line demonstration in pulse crops conducted in different agroclimatic Zone of Madhya Pradesh and Odissa ZCU for TOT Project Zone VII, Jabalpur 1998, P37.

6. Dayanand VRK, Mehta SM. Boosting mustard production through front line demonstrations. Indian Res J Ext Edu 2012;12(3):121-123.

7. Dhawan RS, Chawla S, Bhaskar P, Punia SS, Angiras R. Effect of pinoxaden, an accase inhibitor on management of aryloxyphenoxypropionate resistant biotype of Phalaris minor, $\mathrm{p}$ 148. In: Proceedings of National Conference on Frontiers in Plant Physiology towards Sustainable Agriculture. Indian Society of Plant Physiology. AAU, Jorhat 2009.

8. FAO. FAO Agricultural Production Statistics 2013. http://faostat3.fao.org

9. Sagar RL, Ganesh Chandra. Front line demonstration on Sesame in West Bengal. Agricultural Extension Review 2013;10:7-10.

10. Singh R, Singh BB, Singh G, Tripathi SS. Evaluation of metribuzine for Phalaris minor control in wheat. Indian Journal of Weed Science 1999;31:155-157.

11. Singh SB. Impact of frontline demonstrations on yield of Wheat (Triticum aestivum) under rain fed Condition in Uttarakhand. International Journal of Science and Technology 2017;6(1):779-786.

12. Singh G, Singh VP. Compatibility of clodinafoppropargyl and fenoxaprop-p-ethyl with carfentrazoneethyl, metsulfuron-methyl and 2, 4-D. Ind. J Weed Sci 2005;37:1-5.
13. Walia US, Singh B. Performance of triasulfuron and carfentrazone-ethyl against broadleaf weeds in wheat. Ind. J Weed Sci 2006;38:237-239.

14. Warde PN, Bhope RS, Chudhary DP. Adoption of dry land horticulture technology. Maharastra J Extn Edu 1991;10(2):108-111.

15. Yadav A, Malik RK. Herbicide Resistant Phalaris minor in Wheat-A Sustainability Issue. Resource Book. Department of Agronomy and Directorate of Extension Education, CCS Haryana Agricultural University, Hisar 2005, P152. 